\title{
Antitumor Effect of Agrimoniin, a Tannin of Agrimonia pilosa LeDEB., on Transplantable Rodent Tumors
}

\author{
Kenichi MIYAMOTO, Nobuharu KISHI and Ryozo KOSHIURA \\ Department of Pharmacology, Hokuriku University School of Pharmacy. \\ Ho-3 Kanagawa-machi, Kanazawa 920-11, Japan
}

Accepted November 8, 1986

\begin{abstract}
The effect of agrimoniin, a tannin contained in Agrimonia pilosa LEDEB., on ascites type and solid type rodent tumors was investigated. When agrimoniin was intraperitoneally (i.p.) administered at dosages over $10 \mathrm{mg} / \mathrm{kg}$ before or after the $M M 2$ cell i.p. inoculation, this tannin almost completely rejected the tumor growth in the mice. This tannin prolonged the life span of mice bearing MM2 or cured by the intravenous or per oral pre- or postmedication. Agrimoniin also inhibited the growth of MH134 and Meth-A solid type tumors. Agrimoniin showed strong cytotoxicity on MM2 cells in vitro, but the activity was diminished to about $4 \%$ of the initial activity by the addition of fetal calf serum to the culture. On the other hand, i.p. injection of agrimoniin increased the number of peripheral white blood cells and the ratio of monocytes. On the 4th day after the i.p. injection of the tannin, cytotoxic adherent peritoneal exudate cells were also increased. The spleen of the mice was enlarged, and the spleen cells possessed the capacity to take up ${ }^{3} \mathrm{H}$-thymidine. Agrimoniin showed weak direct migration activity against spleen cells from non-treated mice. These results indicate that agrimoniin is a potent antitumor tannin and suggest that the antitumor effect may be due to this tannin enhancing the immune response of the host animals through the actions on tumor cells and some immunocytes.
\end{abstract}

A number of plants containing tannins have been traditionally known to be effective against cancers and tumors. However, since the isolation of pure tannins from the plants has been difficult, we could not determine the characteristics and activities of each tannin until now. Agrimonia pilosa LEDEB. has been traditionally known as a plant with effective antitumor activity, and it is being used for cancer therapy in China today (1). Recently, Okuda et al. (2) have isolated agrimoniin, a dimeric ellagitannin, from this plant, and we have indicated that this tannin is the main antitumor active constituent of this plant (3).

The present study deals with the effect of agrimoniin on ascites and solid type mouse tumors.

\section{Materials and Methods}

Agents: Agrimoniin (Fig. 1) was isolated by the method described in the previous paper
(3). OK-432 (Chugai), concanavalin A (Con A, Maruzen Oil), Escherichia coli lipopolysaccharide (E. coli LPS, Wako Pure Chemical), ${ }^{3} \mathrm{H}$-thymidine $\left({ }^{3} \mathrm{H}-\mathrm{TdR}\right.$, New England Nuclear) were purchased from commercial sources. Agents were dissolved in physiological buffered saline (PBS) before use.

Animals and tumors: Six-weeks-old ddY, $\mathrm{C} 3 \mathrm{H} / \mathrm{He}$ and $\mathrm{BALB} / \mathrm{C}$ mice were purchased from Shizuoka Laboratory Animal Center. Hamamatsu. MM2 mammary carcinoma and $\mathrm{MH} 134$ hepatoma were maintained by intraperitoneal (i.p.) passage at weekly intervals in female $\mathrm{C} 3 \mathrm{H}$ mice. Meth-A fibrosarcoma was maintained in a similar manner in female BALB/c mice.

Acute toxicity on mice: Female and male ddY mice were i.p., intravenously (i.v.), or per orally (p.o.) administered with graded doses of agrimoniin. The $50 \%$ lethal dose 


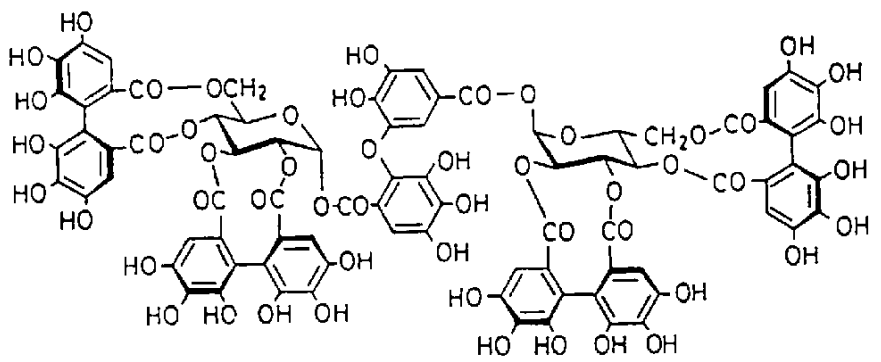

Fig. 1. Structure of agrimoniin.

(LD50) was calculated from the number of dead animals 7 days after the administration by the method of Litchfield-Wilcoxon.

Antitumor experiments in mice: Agrimoniin was i.p., i.v. or p.o. given to the mice according to the treatment schedules indicated in the tables. Female $\mathrm{C} 3 \mathrm{H} / \mathrm{He}$ mice were i.p. inoculated with $5 \times 10^{5} \mathrm{MM} 2$ mammary carcinoma cells on day 0 . Sixty days after the cell inoculation, survivors were killed and autopsied. For solid type tumors, female $\mathrm{C} 3 \mathrm{H} / \mathrm{He}$ and $\mathrm{BALB} / \mathrm{C}$ mice were subcutaneously (s.c.) inoculated at the left inguinal region with $2 \times 10^{6} \mathrm{MH} 134$ cells and $1 \times 10^{6}$ Meth-A fibrosarcoma cells, respectively, on day 0 . Thirty-two days after the MH134 cell inoculation and twenty-five days after the Meth-A cell inoculation, the tumors were removed and weighed.

Assay of direct cytotoxicity against MM2 cells: A $2 \mathrm{ml}$ aliquot of tumor cells $\left(2 \times 10^{5}\right.$ cells $/ \mathrm{ml}$ ) prepared in RPMI 1640 medium with or without $10 \%$ fetal calf serum was added with graded concentrations of agrimoniin and incubated at $37^{\circ} \mathrm{C}$ for $2 \mathrm{hr}$ Then, the cells were washed with Hanks solution and further incubated in RPMI 1640 medium supplemented with 10\% fetal calf serum and $10 \mu \mathrm{M}$ mercaptoethanol at $37^{\circ} \mathrm{C}$ in a humidified $\mathrm{CO}_{2}$ incubator for $48 \mathrm{hr}$. The viable cells were assayed by a dye exclusion method with 0.2\% Trypan Blue.

Assay of number and cell population of peripheral white blood cells (WBC) and peritoneal exudate cells (PEC): The peripheral blood and PEC were collected from female $\mathrm{C} 3 \mathrm{H} / \mathrm{He}$ mice i.p. treated with agrimoniin or OK-432. Total number of $\mathrm{WBC}$ and PEC was estimated by using a Bürker-Türk hemocytometer. The determination of the cell population was carried out after Giemsa stain.

Cytotoxic activity of adherent PEC: PEC $\left(5 \times 10^{6}\right.$ celis $\left./ 2 \mathrm{ml}\right)$ suspended in RPMl 1640 medium supplemented with $10 \%$ fetal calf serum and $10 \mu \mathrm{M}$ mercaptoethanol were placed on a $35-\mathrm{mm}$ plastic petri dish and cultured for $1 \mathrm{hr}$. After the wash-out, nonadherent cells, a $2 \mathrm{ml}$ aliquot of tumor cells $\left(5 \times 10^{5}\right.$ cells) suspended in the culture medium and $0.1 \mu \mathrm{Ci}{ }^{3} \mathrm{H}-\mathrm{TdR}$ were added and cultured for $24 \mathrm{hr}$ at $37^{\circ} \mathrm{C}$. After the incubation. cells were harvested on a glass fiber filter (Whatman, GF/C) and washed with cold PBS, $5 \%$ trichloroacetic acid and an ethanol: ether $(3: 1, \mathrm{~V} / \mathrm{V})$ mixture. The radioactivity on the filter was counted in a toluenebased scintillator (4 g PPO, $0.1 \mathrm{~g}$ POPOP. 1 | toluene) by a Beckman LS-230 liquid scintillation counter.

${ }^{3} \mathrm{H}-\mathrm{TdR}$ uptake by spleen cells: The in vivo (i.p.) or in vitro stimulated cells $\left(1 \times 10^{\circ}\right)$ were cultured with $0.1 \mu \mathrm{Ci}{ }^{3} \mathrm{H}-\mathrm{TdR}$ for $24 \mathrm{hr}$ and harvested on a glass filter, and the radioactivity on the filter was counted by the method described above.

\section{Results}

Acute toxicity on mice: Most of the mice i.p. injected with over $10 \mathrm{mg} / \mathrm{kg}$ of agrimoniin developed stretching and writhing reactions within $5 \mathrm{~min}$. Then, mice that received lethal doses fell in a depressed and bradypnic state and gradually died after myoclonus within 4 days. The remaining mice recovered to a normal state within 7 days after the administration. In i.v. administration, the tail of the injection site developed cyanosis and necrosis. Symptoms were similar to those of the i.p. administration except for the stretching 
and writhing reactions, and the mice recovered to a normal state at an earlier time compared with the i.p. administration. Mice p.o. administered with $1000 \mathrm{mg} / \mathrm{kg}$ developed only a slight depressed state for about $2 \mathrm{hr}$. The LD50 values of agrimoniin are shown in Table 1. There was no difference between the sexes in each administration route.

Antitumor effect on MM2 ascites type tumor: As shown in Table 2, when i.p. injected with a single dosage over about one-tenth of the LD50 of agrimoniin before the tumor cell inoculation, the mice almost completely rejected the tumor growth. Mice who were i.p. injected with lower doses at 4 days before the inoculation could not reject the tumor. and the tumor growth in 2 or 3 out of examined mice was observed until 2-4 weeks, but regressed by 60 days after the inoculation. The i.v. $(3 \mathrm{mg} / \mathrm{kg})$ and p.o. $(300 \mathrm{mg} / \mathrm{kg})$ premedications could not completely reject the tumor. but caused tumor cell regression even at 14 days before the tumor cell inoculation. Agrimoniin was effective also in the postmedication by each administration route (Table 3 ). Some of the tumor-bearing mice died within a similar time as non-treated control mice, but the remaining mice showed inhibition of tumor growth.

Antitumor effect on MH134 and Meth-A solid type tumors: $\mathrm{MH} 134$-bearing $\mathrm{C} 3 \mathrm{H} / \mathrm{He}$ mice were given agrimoniin i.p. once a day

Table 1. Acute toxicity of agrimoniin in mice

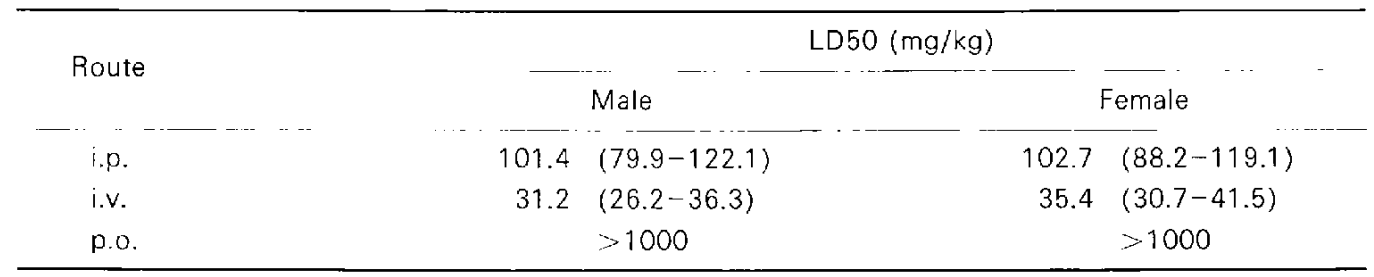

( ): $95 \%$ confidence interval.

Table 2. Antitumor effect of premedication with agrimoniin on MM2 ascites type tumor

\begin{tabular}{|c|c|c|c|c|c|c|}
\hline \multirow[t]{2}{*}{ Route } & \multirow{2}{*}{$\begin{array}{l}\text { Treatment } \\
\text { schedule }\end{array}$} & \multirow{2}{*}{$\begin{array}{c}\text { Dose } \\
(\mathrm{mg} / \mathrm{kg})\end{array}$} & \multirow{2}{*}{$\begin{array}{l}\text { Survival daysa } \\
\text { (mean } \pm \text { S.D.) }\end{array}$} & \multirow[t]{2}{*}{$\%$ ILS } & \multicolumn{2}{|c|}{ 60-day survivorse } \\
\hline & & & & & Rejectors & Regressors \\
\hline \multirow[t]{7}{*}{ i.p. } & on day -14 & 10 & - & $>198$ & 6 & 0 \\
\hline & on day -7 & 10 & 51 & 153 & 5 & 0 \\
\hline & on day -4 & 30 & - & $>198$ & 6 & 0 \\
\hline & & 10 & - & $>198$ & 6 & 0 \\
\hline & & 3 & $21.5 \pm 1.6$ & 6 & 0 & 3 \\
\hline & & 1 & $20.7 \pm 0.7$ & 2 & 0 & 2 \\
\hline & on day -1 & 10 & $\rightarrow$ & $>198$ & 6 & 0 \\
\hline \multirow[t]{4}{*}{ i.v. } & on day -14 & 3 & $23.0 \pm 1.4$ & 14 & 0 & 4 \\
\hline & on day -7 & 3 & $23.5 \pm 3.5$ & 17 & 0 & 4 \\
\hline & on day -4 & 3 & $23.0 \pm 0.0$ & 14 & 0 & 4 \\
\hline & on day -1 & 3 & $20.3 \pm 3.3$ & 0 & 0 & 2 \\
\hline \multirow[t]{4}{*}{ p.o. } & on day -14 & 300 & $20.0 \pm 1.4$ & -1 & 0 & 4 \\
\hline & on day -7 & 300 & $27.0 \pm 0.0$ & 34 & 0 & 5 \\
\hline & on day -4 & 300 & $21.5 \pm 0.6$ & 7 & 0 & 2 \\
\hline & on day - 1 & 300 & $22.0 \pm 1.6$ & 9 & 0 & 1 \\
\hline Control & & & $20.2 \pm 1.8$ & - & 0 & 0 \\
\hline
\end{tabular}

aExcluding 60 -day surviors. $\mathrm{b}[(\mathrm{T}-\mathrm{C}) / \mathrm{C}] \times 100$, T: mean survival days of treated mice, $\mathrm{C}$ : mean survival days of non-treated control mice. eNumber of mice completely rejecting the tumor inoculation (rejectors) and resulted in the tumor regression (regressors) out of 6 examined mice in a group at 60 days after the tumor cell inoculation. 
Table 3. Antitumor effect of postmedication with agrimoniin on MM2 ascites type tumor

\begin{tabular}{|c|c|c|c|c|c|c|}
\hline Route & $\begin{array}{l}\text { Treatment } \\
\text { schedule }\end{array}$ & $\begin{array}{c}\text { Single dosage } \\
(\mathrm{mg} / \mathrm{kg})\end{array}$ & $\begin{array}{l}\text { Survival days" } \\
\text { (mean } \pm \text { S.D.) }\end{array}$ & $\%$ ILSb & $\begin{array}{r}\text { 60-day } \\
\text { Rejectors }\end{array}$ & $\begin{array}{l}\text { Survivors" } \\
\text { Regressors }\end{array}$ \\
\hline i.p. & on days $1,4,7$ & $\begin{array}{r}30 \\
10 \\
3\end{array}$ & $\begin{array}{c}53 \\
- \\
21.2 \pm 0.8\end{array}$ & $\begin{array}{r}190 \\
>228 \\
16\end{array}$ & $\begin{array}{l}4 \\
3 \\
0\end{array}$ & $\begin{array}{l}1 \\
3 \\
0\end{array}$ \\
\hline i.v. & on days $1,4,7$ & $\begin{array}{r}10 \\
3 \\
1\end{array}$ & $\begin{array}{l}21.3 \pm 3.8 \\
21.3 \pm 1.5 \\
28.7 \pm 14.4\end{array}$ & $\begin{array}{l}16 \\
16 \\
56\end{array}$ & $\begin{array}{l}0 \\
0 \\
0\end{array}$ & $\begin{array}{l}2 \\
3 \\
3\end{array}$ \\
\hline po. & on days $1-7$ & $\begin{array}{r}1000 \\
300 \\
100 \\
30\end{array}$ & $\begin{array}{l}22.0 \pm 2.0 \\
26.5 \pm 8.8 \\
19.6 \pm 1.9 \\
26.9 \pm 12.4\end{array}$ & $\begin{array}{r}20 \\
45 \\
7 \\
47\end{array}$ & $\begin{array}{l}0 \\
0 \\
0 \\
0\end{array}$ & $\begin{array}{l}0 \\
1 \\
2 \\
2\end{array}$ \\
\hline Control & & & $18.3 \pm 0.8$ & - & 0 & 0 \\
\hline
\end{tabular}

a,b,c Described in the footnote of Table 2.

Table 4. Antitumor activity of agrimoniin against MH134 and Meth-A solid type tumors

\begin{tabular}{|c|c|c|c|c|c|}
\hline Tumor & Route & $\begin{array}{l}\text { Treatment } \\
\text { schedule }\end{array}$ & $\begin{array}{l}\text { Single dosage } \\
(\mathrm{mg} / \mathrm{kg})\end{array}$ & $\begin{array}{l}\text { Tumor weightia } \\
\text { (g) }\end{array}$ & $\%$ inhibition $^{b}$ \\
\hline \multirow[t]{7}{*}{$\mathrm{MH1} 34$} & i.p. & on days $1-12$ & 10 & $1.46 \pm 1.30(2)$ & 53.8 \\
\hline & & & 3 & $0.98 \pm 0.99(5)$ & 68.9 \\
\hline & & & 1 & $1.58 \pm 1.20(2)$ & 50.0 \\
\hline & i.v. & on days 7.10 & 10 & $1.23 \pm 1.54(4)$ & 61.2 \\
\hline & & & 3 & $1.14 \pm 1.26(4)$ & 63.9 \\
\hline & & & 1 & $2.05 \pm 1.31$ & 35.1 \\
\hline & & & 0 & $3.16 \pm 1.82(0)$ & 一 \\
\hline \multirow[t]{4}{*}{ Meth-A } & i.p. & on days $10-18$ & 10 & $2.38 \pm 0.36(0)$ & 30.2 \\
\hline & & & 3 & $1.72 \pm 0.54(2)$ & 49.8 \\
\hline & & & 1 & $3.23 \pm 0.48(0)$ & 5.4 \\
\hline & & & 0 & $3.42 \pm 0.45(0)$ & - \\
\hline
\end{tabular}

Experiments were terminated on day 32 for MH134 and on day 25 for Meth-A. aMean \pm S.D. Parentheses indicate the number of primary tumor regressors out of ten examined mice in a group. ${ }^{b}[(C-T) / C] \times 100$. $T$ : mean weight of tumor in the test group. $C$ : mean weight of tumor in the control group.

for 12 days from day 1 to 12 or given the drug i.v. on days 7 and 10. Agrimoniin significantly suppressed the tumor growth and caused complete regression of the primary tumor in several mice by both types of administrations (Table 4), but the mice still died due to lymphnodes and lung metastasis (data not shown). On Meth-A-bearing BALB/C mice, 3 and $10 \mathrm{mg} / \mathrm{kg}$ of agrimoniin markedly inhibited the tumor growth when it was i.p. administered once a day for 9 days from day 10 to 18.

In vitro cytotoxic activity against MM2 cells: MM2 cells were treated with agrimoniin for $2 \mathrm{hr}$ in the absence or presence of fetal calf serum. Figure 2 shows the dose-response curves obtained after the culture for 2 days. Agrimoniin possessed potent direct cytotoxicity, and its IC50 was $2.6 \mu \mathrm{g} / \mathrm{ml}$, but the effect was significantly decreased to an IC50 of $62.5 \mu \mathrm{g} / \mathrm{ml}$ by the addition of serum.

Influence on the number and cell population of peripheral WBC: $\mathrm{C} 3 \mathrm{H} / \mathrm{He}$ mice were i.p. administered $10 \mathrm{mg} / \mathrm{kg}$ of agrimoniin. The total number of WBC significantly increased 4 to 10 days after the injection. In the cell population, the percentage of monocytes and eosinophils was markedly higher than that of the control. After 14 days, the total cell number and the percentage of 
eosinophils decreased to the control level. but the percentage of monocytes was still high (Fig. 3).

Influence on PEC: At 4 days after the i.p.

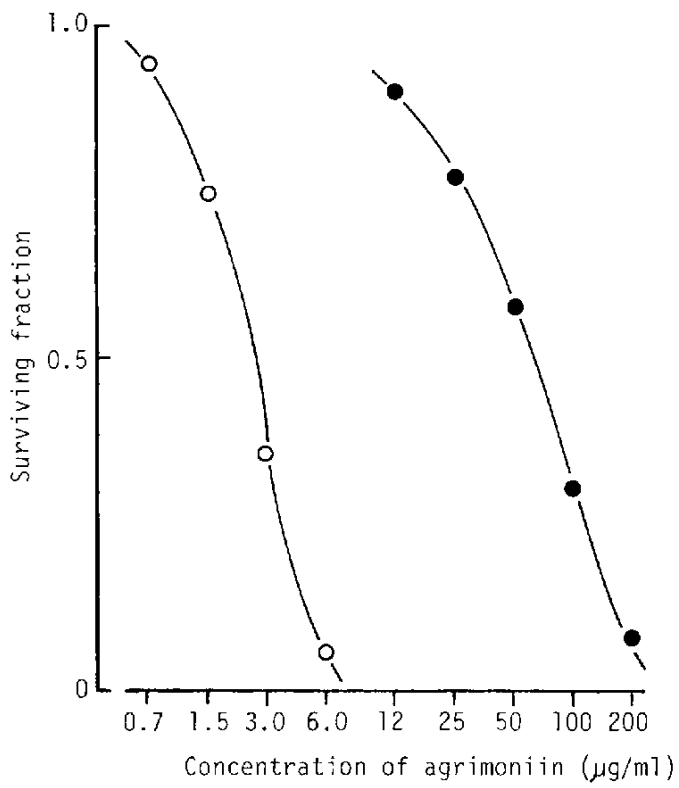

Fig. 2. Direct cytotoxic activity of agrimoniin against MM2 cells. Cells $\left(2 \times 10^{5}\right.$ cells $\left./ \mathrm{ml}\right)$ were treated with graded concentrations of agrimoniin in the absence (O) or in the presence (O) of $10 \%$ fetal calf serum for $2 \mathrm{hr}$. The treated cells were incubated for $48 \mathrm{hr}$, and viable cells number was determined. Data are the means of triplicate determinations. injection, the number of PEC was significantly increased in a dose-dependent manner (Fig. 4). The PECs from non-treated mice had the following composition: $63.3 \pm 4.7 \%$ monocytes or phagocytes, $7.3 \pm$ $3.1 \%$ polymorphonuclearleukocytes (PML), and $32.7 \pm 5.8 \%$ lymphocytes. Those from the mice treated with $10 \mathrm{mg} / \mathrm{kg}$ of agrimoniin before 4 days were composed of $57.5 \pm 4.4 \%$ monocytes, $23.0 \pm 2.6 \% \mathrm{PML}$, and $19.5 \pm 7.0 \%$ lymphocytes. The adherent PECs, which seemed to be macrophages, markedly inhibited ${ }^{3} \mathrm{H}-\mathrm{TdR}$ uptake by MM2 celis and MH134 cells (Table 5).

Induction of ${ }^{3} \mathrm{H}-\mathrm{TdR}$ uptake capacity of spleen cells: The observations on spleen after the i.p. injection with agrimoniin and OK-342 are shown in Fig. 5. The spleen of the mice treated with this tannin enlarged and the weight increased. The non-adherent spleen cells from the mice treated with both agents had the ability to take up ${ }^{3} \mathrm{H}-\mathrm{TdR}$. Additionally, agrimoniin showed slight migration activity against spleen cells from non-treated mice (Table 6).

\section{Discussion}

Agrimonia pilosa LedEB. has been traditionally known as an antitumor plant. While many studies on the constituents of this plant have been carried out and several constituents have been isolated, not much

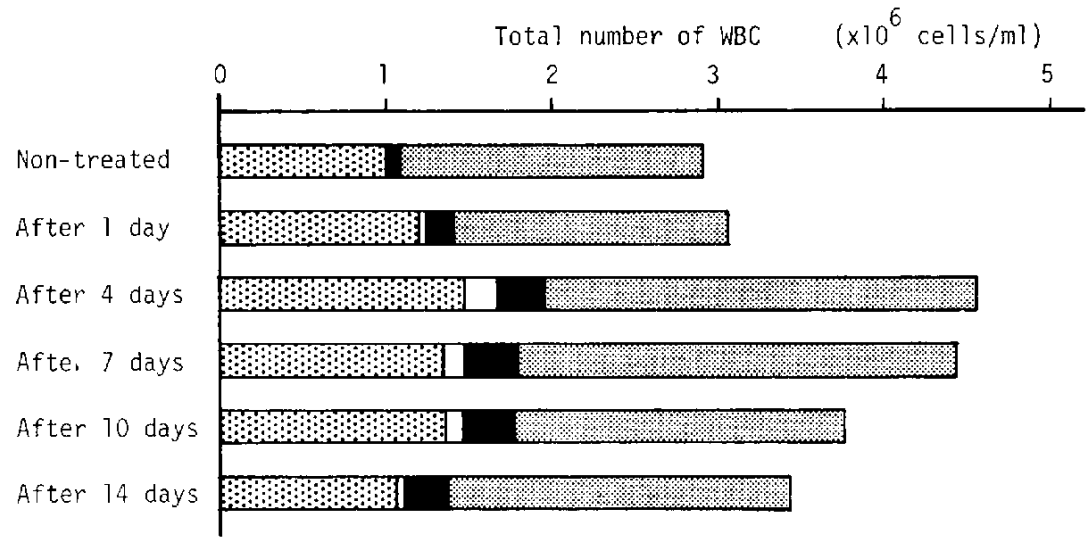

Fig. 3. Hematological findings in mice treated with agrimoniin. Five $\mathrm{C} 3 \mathrm{H} / \mathrm{He}$ mice in a group were i.p. administered with agrimoniin $(10 \mathrm{mg} / \mathrm{kg})$ : and after the indicated days, the number and population of WBC in peripheral blood were determined. Data are the means of 5 mice. Neutrophils: $;:$, eosinophils: $\square$, monocytes: $\square$. lymphocytes: 


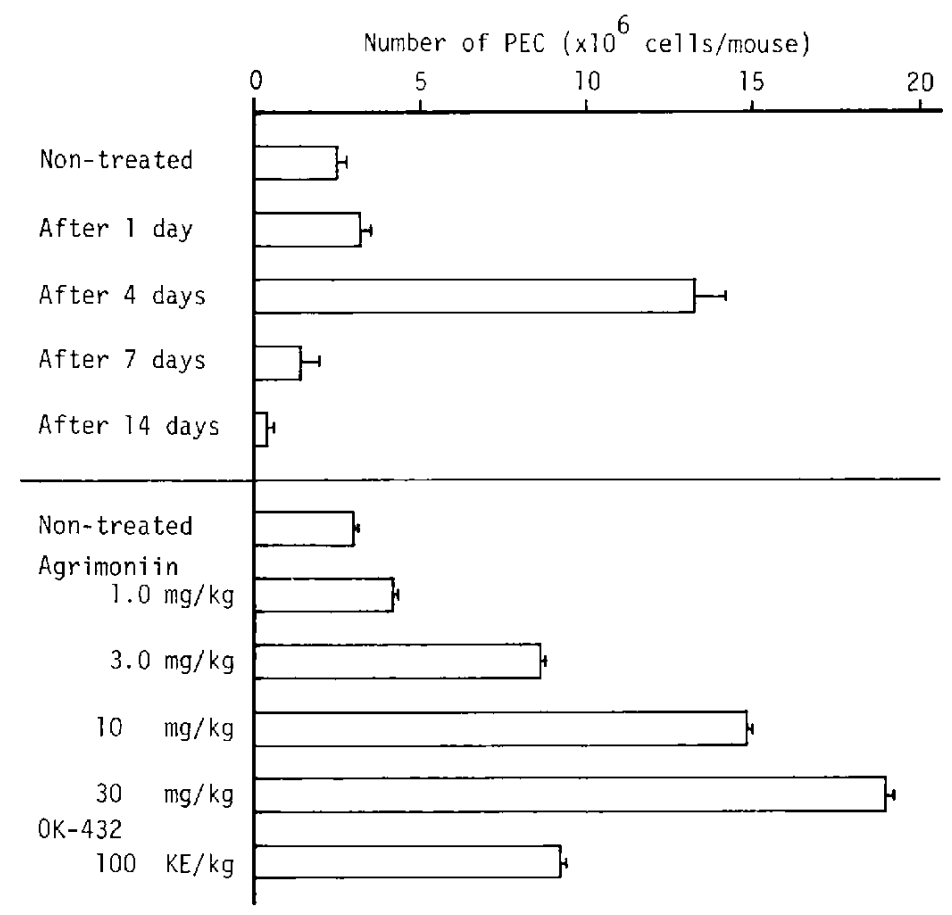

Fig. 4. Change of number of PEC in mice treated with agrimoniin. Upper panel: Experiments were carried out after the indicated days of the i.p. injection with agrimaniin $(10 \mathrm{mg} / \mathrm{kg})$. Lower panel: Experiments were carried out after 4 days of the i.p. injection with the indicated doses of agrimoniin or OK-432. Data are the mean \pm S.D. (bar) of triplicate determinations, of 5 mice.

Table 5. Cytotoxic activity of adherent PEC on MM2 cells and MH134 cells

\begin{tabular}{lccc}
\hline $\begin{array}{c}\text { Adherent } P E C \\
\text { induced by }\end{array}$ & & \multicolumn{2}{c}{$\begin{array}{c}\text { \% inhibition of }{ }^{3} \mathrm{H}-\mathrm{TdR} \text { uptake by } \\
\text { MMH1 }\end{array}$} \\
\cline { 2 - 3 } Agrimoniin & $30 \mathrm{mg} / \mathrm{kg}$ & $42.6 \pm 2.0$ & $41.9 \pm 5.1$ \\
& 10 & $54.7 \pm 3.1$ & $54.5 \pm 1.3$ \\
& 3 & $48.3 \pm 1.5$ & $40.8 \pm 2.6$ \\
& 1 & $19.3 \pm 2.4$ & $6.4 \pm 3.4$ \\
OK-432 & $100 \mathrm{KE} / \mathrm{kg}$ & $55.6 \pm 0.9$ & $50.4 \pm 4.2$ \\
Non & & $-3.1 \pm 1.6$ & $-1.3 \pm 0.1$ \\
\hline
\end{tabular}

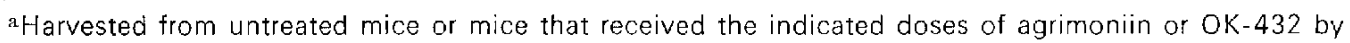
intraperitoneal injection 4 days previously. bMean of triplicate determination \pm S.E. Mean of ${ }^{3} \mathrm{H}-\mathrm{TdR}$ uptake by MM2 cells. MH134 cells and adherent PEC was $6,320 \mathrm{cpm}, 4,418 \mathrm{cpm}$ and $146 \mathrm{cpm}$, respectively.

evidence exists that each of them shows antitumor activity (4-9). Previously, we have indicated that the methanol extract from roots of Agrimonia pilosa LEDEB. showed potent antitumor activity against several transplantable rodent tumors and suggested that this plant contains some antitumor constituents
(10). We have demonstrated in the earlier paper (3) that agrimoniin. which is a tannin contained in large amounts in this plant, is the main antitumor active constituent of this plant. The results of the present study indicate that agrimoniin is effective on syngeneic rodent tumors. When agrimoniin was i.p. 
Weight ratio of spleen versus body (\%)

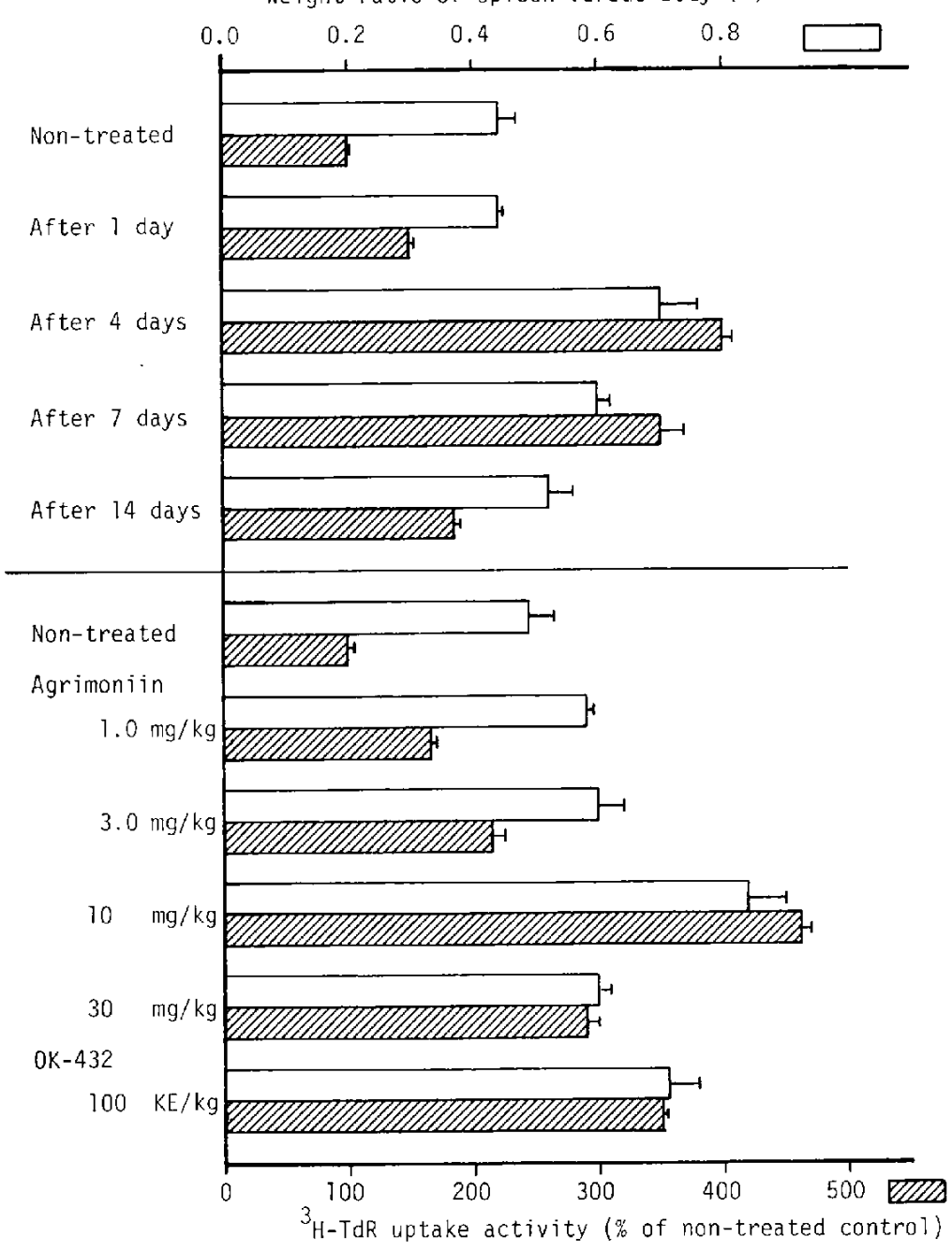

Fig. 5. Change of spleen weight and ${ }^{3} \mathrm{H}-\mathrm{TdR}$ uptake activity of the spleen cells from mice treated with agrimoniin. Upper panel: Experiments were carried out after the indicated days of the i.p. injection with agrimoniin $(10 \mathrm{mg} / \mathrm{kg}$ ). Lower panel: Experiments were carried out after 4 days of the i.p. injection with the indicated doses of agrimoniin or OK-432. Data are the mean \pm S.D. (bar) of triplicate determinations, of 5 mice. The mean of the ${ }^{3} \mathrm{H}-\mathrm{TdR}$ uptake by spleen cells from the non-treated mice was $2,774 \mathrm{cpm}$.

administered before or after the i.p. inoculation of MM2 mammary tumor cells, this tannin showed strong antitumor activity and almost completely rejected the tumor growth at doses over $10 \mathrm{mg} / \mathrm{kg}$. Even by the injection at 14 days before the cell inoculation, complete rejection was obtained. This tannin prolonged the lifespan and cured many of the mice bearing MM2 by i.v. and p.o. pre- and postmedication. Agrimoniin was also effective on solid type tumors such as $\mathrm{MH} 134$ hepatoma and Meth-A fibrosarcoma.

In the observation of acute toxicity. agrimoniin caused stretching and writhing reactions by the i.p. injection and cyanosis and necrosis in the tail which was the i.v. injection site. These were considered inflammatory reactions based on the astringent 
Table 6. In vitro stimulation of spleen cells from non-treated mice

\begin{tabular}{lccc}
\hline Agent & $\begin{array}{c}\text { Concentration } \\
(\mu \mathrm{g} / \mathrm{ml})\end{array}$ & $\begin{array}{c}\times 10^{3} \mathrm{cpm} \\
(\text { mean } \pm \mathrm{S} . \mathrm{E} .)\end{array}$ & $\begin{array}{c}{ }^{3} \mathrm{H}-\mathrm{TdR} \text { uptake } \\
\% \text { of } \\
\text { control }\end{array}$ \\
\hline Agrimoniin & 30 & $2.33 \pm 0.61$ & 167 \\
& 10 & $4.04 \pm 0.41$ & 291 \\
& 3 & $2.17 \pm 0.25$ & 156 \\
E. coli LPS & 1 & $1.46 \pm 0.04$ & 105 \\
Con A & 1.0 & $35.2 \pm 1.0$ & 2535 \\
& 0.1 & $18.8 \pm 0.8$ & 1349 \\
Control & 3.0 & $14.8 \pm 0.2$ & 1062 \\
\hline
\end{tabular}

Spleen cells from normal $\mathrm{C} 3 \mathrm{H} / \mathrm{He}$ mice $\left(1 \times 10^{6}\right)$ were incubated with each agent for $24 \mathrm{hr}$ and were further incubated with $0.1 \mu \mathrm{Ci}{ }^{3} \mathrm{H}-\mathrm{TdR}$ for $24 \mathrm{hr}$. Experiments were carried out in triplicate.

actions of this tannin. The total number of peripheral WBC, the ratio of monocytes and eosinophils, and the spleen weight increased after the administration, and these responses of the host commonly occur after the administration of inflammatics. PMLs also increased in the peritoneal fluid after the i.p. injection of this tannin, and this increase may be due to the local inflammation in the abdominal cavity. However, because the macrophagelike cells and spleen cells from the mice treated with this compound showed cytotoxic activity and self growing ability, respectively, the induction of these cells does not seem to be the result of a simple inflammatory reaction. A streptococcal preparation, OK432, is known to have effective antitumor and immune modulatory activities (11-13). This study also confirmed the host-mediated antitumor action of OK-432 through the induction of cytotoxic macrophages and self growing lymphocytes.

On the other hand, there are a few reports that the antitumor activity of Agrimonia pilosa is attributed to only a direct action to tumor cells (14). In this in vitro experiment. agrimoniin was highly cytotoxic to MM2 cells in the absence of calf serum, but the activity was markedly diminished by the addition of serum to the culture. Therefore, when this tannin was administered to the animal, it may bind to some entity (e.g., protein) in the host, and its direct cytotoxicity to the tumor cells seems to be very weak. However, one may consider that this tannin binds to target cells such as tumor cells and enhances the antigen-antibody reaction as described for other tannins with an unknown mechanism.

Bacteria $(11,15,16)$ and their components (17-19), some polysaccharides (20-22) and low molecular weight compounds such as levamizole (23) and bestatin (24) are wellknown as immunopotentiators. Agrimoniin presented in this study is a plant tannin. Its action mechanisms may be therefore thought to be different from the existing agents by its characteristic structure and pharmacological activities. Further detailed investigations for mechanisms of the antitumor activity are needed.

\section{References}

1 Sugi, M.: Cancer therapy by Chinese crude drugs. In Cancer Therapy in China Today, Edited by Kondo, K., p. 95-96. Shizensha, Tokyo (1977)

2 Okuda, T., Yoshida, T., Kuwahara, M., Memon, M.U. and Shingu, T.: Tannins of Rosaceous medicinal plants. I. Structures of popentillin, agrimonic acids $A$ and $B$, and agrimoniin, a dimeric ellagitannin. Chem. Pharm. Bull. (Tokyo) 32, 2165-2173 (1984)

3 Miyamoto, K., Koshiura, R., Ikeya, Y. and Taguchi, H.: Isolation of agrimoniin, an antitumor constituent. from the roots of Agrimonia pilosa LEDEB. Chem. Pharm. Bull. (Tokyo) 33, 3977-3981 (1985)

4 Yamato, M.: Studies on the constituents of the 
rhizome of Agrimonia pilosa LEDEB. III. Kumamoto Pharm. Bull. 5, 330-331 (1962)

5 Koyama, T., Yamato, M. and Ideguchi, S.: Studies on the pharmacological action of agrimonolide. Kumamoto Pharm. Bull. 5, 334335 (1962)

6 Kimura, Y., Takido, M. and Yamanouchi, S.: Studies on the standardization of crude drugs. XI. Constituent of Agrimonia ilosa VAR, japonica. Yakugaku Zasshi 88, 1355-1357 (1968) (Abs. in English)

7 Shenyahg College of Pharmacy, Liaoning Institute of Pharmaceutics and Institute of Materia Medica, Chinese Academy of Medical Sciences: Elucidation of the structure of agrimophol. Acta Chimica Sinica 35, 87-96 (1977) (Abs. in English)

8 Cheng, C., Chu, T., Wang, H., Huang, P. and Chin, K: Studies on the active principles of Shianhotsao. II. The structures of agrimol A, B. $D$ and E. Acta Chimica Sinica 36, 35-41 (1978) (Abs. in English)

9 Koshiura, R., Miyamoto, K., Takada, Y. and Kiriyama, N.: Studies on the constituents of Agrimoria pilosa LEDEB. I. Biological activities of the acidic fraction soluble in $n$-hexane of the roots. Yakugaku Zasshi 100, 1167-1170 (1980) (Abs. in English)

10 Koshiura, R., Miyamoto, K.. Ikeya, Y. and Taguchi, $H_{\text {.: }}$ Antitumor activity of methanol extract from roots of Agrimonia pirosa LEDEB. Japan. J. Pharmacol. 38, 9-16 (1985)

11 Okamoto, H., Shoin, S. and Koshimura, S.: Streptolysin S-forming and antitumor activities of group A streptococci. In Bacterial Toxins and Cell Membranes. Edited by Jeljaszewicz, J. and Wadstrom, T., p. 259-289. Academic Press, New York (1978)

12 Kai, S., Tanaka, J., Nomoto, K. and Torisu, M.: Studies on the immunopotentiating effects of a streptococcal preparation, OK-432. I. Enhancement of $T$ cell-mediated immune responses of mice. Clin. Exp. Immunol. 37, 98-105 (1979)

13 Murayama, T., Natsuume-Sakai, S., Ryoyama, K. and Koshimura, S.: Studies on the properties of a streptococcal preparation, OK-432 (NSCB116209), as an immunopotentiator. II. Mechanism of macrophage activation by OK-432. Cancer Immunol. Immunother. 12, 141-146 (1982)

14 Sato, A.: Antitumor activity of some crude drugs (XII). Antitumor activity of Agrimonia pilosa
Ledeb. (II). Proc. Japan. Cancer Assoc. (43rd), p. 280 (1984) (in Japanese)

15 Biozzi, G., Stiffel, C., Halpern, B.N. and Mouton, D.: Effect de l'inoculation du bacille de CalmetteGuerin sur le développment de la tumeur ascitique d'Ehrlich chez la souris. C. R. Soc. Biol. 153, 987-989 (1959) (Abs. in English)

16 Halpern, B.N., Biozzi, G., Stiffel, C. and Mouton, D.: Inhibition of tumour growth by administration of killed Corynebacterium parvum. Nature 212, 853-854 (1966)

17 Coley, W.B.: The treatment of inoperable sarcoma with the mixed toxins of erysipeals and bacillus prodigiosus. JAMA $31,389-395,456-465$ (1988)

18 Azuma, I., Yamawaki, M., Uemiya, M., Saiki, I., Tanio, Y., Kobayashi, S., Fukuda, T., Imada. I. and Yamamura, $Y$.: Adjuvant and antitumor activities of quinoyl- $\mathrm{N}$-acetylmuramyl-dipeptides. Japan. J. Cancer Res. (Gann) 70, 847848 (1979)

19 Miyamoto, K., Koshiura, R., Hasegawa, T. and Kato, N.: Antitumor activity of Klebsiel/a 03 lipopolysaccharide in mice. Japan. J. Pharmacol. 36, 51-57 (1984)

20 Abe, S., Yamazaki, M. and Mizuno, D.: Correlation of difference in antigenicity of four 3 methylcholanthrene-induced tumors in syngeneic mice with susceptibility of tumors to an immunopotentiator, PSK. Japan. J. Cancer Res. (Gann) 69, 223-228 (1978)

21 Chihara, G., Maeda, Y., Hamuro, J., Sasaki, T. and Fukuoka, F.: Inhibition of mouse sarcoma 180 by polysaccharide from Lentinus edodes (BERK.) SING. Nature 222, 687-688 (1969)

22 Hasegawa, T., Ohta, M.r Kido, N., Kato, N., Miyamoto, K. and Koshiura, R.: Comparative studies on antitumor activity of Klebsiel/a 03 lipopolysaccharide and its polysaccharide fraction in mice. Japan. J. Pharmacol. 38, 355360 (1985)

23 Versijp, G., Van Zwet, T.L. and Van Furth, R.: Levamizole and functions of peritoneal macrophages. Lancet 1, 798 (1975)

24 Umezawa, H.: Small molecular weight immunomodifiers produced by microorganisms: their screening and discovers and the genetics of microbial secondary metabolites. In Small Molecular Immuno-Modifiers of Microbial Origin-Fundamental and Clinical Studies of Bestatin. Edited by Umezawa, H., p. 1, Japan Scientific Societies Press. Tokyo (1981) 